\title{
Public Transport Performance Based on the Potential Demand and Service Area (Case Study: Jakarta Public Transport)
}

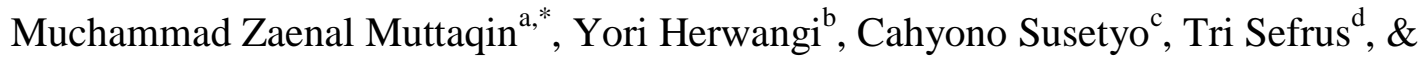 \\ Muhammad Subair \\ ${ }^{a}$ Civil Engineering Department, Universitas Islam Riau, Pekanbaru, Indonesia \\ ${ }^{b}$ Department of Architecture and Planning, Universitas Gadjah Mada, Yogyakarta, Indonesia \\ ${ }^{c}$ Department of Urban and Regional Planning, Institut Teknologi Sepuluh November, Surabaya, Indonesia \\ ${ }^{d}$ Department of Architecture and Planning, Universitas Gadjah Mada, Yogyakarta, Indonesia \\ ${ }^{e}$ Pulse Lab, Jakarta, Indonesia
}

\begin{abstract}
The effectiveness and efficiency of public transport should be a priority for transportation in developing cities. Despite the efforts from the government to improve public transportation, in Jakarta City, Indonesia, there is still $9.93 \%$ increase of private vehicle annually per year. In detail, contributor for increasing vehicle in Jakarta is motorcycles with an average annual increase of $10.54 \%$ in every year, followed by an increase in the percentage of passenger cars by $8.75 \%$. In contrast, the number of public transportation increased only by $1.74 \%$. This research did the evaluation for public transport service in Jakarta by availability and accessibility for them. Neighbourhood analysis and Proximity analysis used in this research. The results of the research showed that major problems in public transportations in Jakarta City are the coverage area of the service, route connectivity, and its accessibility for public facilities. There are only $7.78 \%$ for coverage area by flexible bus stop service with average walking distance by $300 \mathrm{~m}$. Thus, there are some areas that are not passed by public transport routes, for about 18.5 million people live in blank spot area.
\end{abstract}

Keywords: Transportation; GIS; Jakarta; Public transport; accessibility.

\section{Introduction}

Jakarta is the most crowded city in Indonesia. It needs good public transportation to support mobility for the residents there as metropolitan city in Indonesia. Based on previously research, people would do the travel for their opportunities to perform essential activities such as economic, social, cultural, and political activities (Lucas, 2012; Ureta, 2008; Preston \& Rajé, 2007). Thus, transport is not primary activity but derived activity for human being. Impact from derived activity could be seen from people's guarantee to do travel activity every time from their origin to their destination, especially for commuters, derived activity for transport would force people to always do it as primary activity. All of demand must be available to support their activity. Public transport as a solution must be a good service which can facilitate mobility from people. Beside, transport activity as derived deman could be negative impacts especially from private vehicle as people's primary modes.. On the other hand, modal share of public transportation in Jakarta has decreased by years. Previously research stated that modal share for public transport has been decrease from 38.3 percent in 2002 to 12.9 percent in 2010 (Ibanez, 2011). Meanwhile, total vehicle on road in Jakarta has highly increased about $9.93 \%$ per year. This number has highest contributor on motorcycle (10.54\%) and passenger cars (8.75\%). Beside, public transport just only increased by $1.74 \%$ (BPS, 2017). It conclude that road in Jakarta dominated by private vehicle.

People have rights to choose their modes. People take more chosen modes with private vehicle than public (Muttaqin \& Zaini, 2017). Low performance in public transport became an internal factor that people unwilling to use them. Local government has been already improved bus route to make closer with consumer and initiated integration 
between local train and bus in Jakarta, but it still not enough to attract people using public transport as their modes. Evaluation for Trans Jakarta as main local bus in Jakarta must be evaluated for better transport in Jakarta. The aim of this study is to evaluate the effectivity and efficiency of public transport network in Jakarta. Based on the data availability, the objectives of this paper will be focused on: 1) identifying the coverage area of existing public transport service; and 2) evaluating public transport efficiency based on the potential demand.

\section{Public Transport Performance}

Public transport as apart of service has same characteristic in its marketing which more focused to make equally between customer need identification until what perceived value for customer. Service marketing has unique thing about domination of customer experience than product. Public transport performance means how public transport can serve customer with comfort and safety. Marketing for service has three concept, contains identification of the services, delivering quality in the service and maximization of customer value (Lovelock \& Gummeson, 2004). Identification for services means a description how service is created to serve customer in their activities. It is a starting point before companies offer their service to customer. Second concept is how to deliver quality in the service which introducing first service to customer, do better service based from customer experience and managing customer's expectation (increase satisfaction with fulfillment of customer wants) and marketing service is maximization marketing potential which make benefit in the service, these are customer who using the service.

\section{Methodology and Data}

\subsection{Data Availability and Scope of the study}

This research used data from public transport network in Jakarta which comprise of Trans Jakarta bus route and non TransJakarta route in geospatial format. It also used population data, public facilities location and Trans Jakarta station location, also land use data. All of data would compare between Service area of Trans Jakarta and Non Trans Jakarta its potential demand in Jakarta area.

Based on the data availability, public transport performance measurement which conducted in this study is in term of availability (coverage of public transport service).

\subsection{Public Transport Performance by Geographic Information System (GIS) Software}

GIS (Geographic Information Systems) software was a tools used for create, modify and analyse map with spatial analysis. This research used them to analyze for performance of public transport. Combination between spatial information of Trans Jakarta with other information in the map, like land use, residential information would be apart for GIS (Dodson, et. al, 2004). Previously research stated that performance of pubic transport by spatial analysis could be done with GIS Software (Currie, et. al, 2009; Kausarian, et. al, 2018 ). Besides, it could combine too with social and economic data to address the transport "needs-gap" for additional information that proposed in this research.

This research used the neighborhood analysis, which generates all coverage area of existing public transport networks in Jakarta. Neighborhood analysis is a method that exist in GIS environment that important when a situation requires relationships between two or more locations, rather than interpret the characteristics at individual locations. The neighbourhood analysis would generally selecting the map region that have same identity in the GIS package to connect one and another. Connected region based on results from neighbourhood analysis could be seen in figure 1. Two or more maps connected and join as new shaped or same shaped with additional information.

Another analysis that used in this research was proximity analysis, which identifies overlapping routes of the transportation fleets. Proximity Analysis is an analysis for geographical analysis based on the distance between layers (Jaelani \& Agung, 2018). Geographic Information Systems (GIS) software would use a buffer process, like building supporting layers around layers within a certain distance to determine relation characteristic between identification for each parts. Thus, proximity analysis used location intelligence using mapping software to calculate distances, for instance distance of hospital location closest to residential area, distance of gas station closest to highway). 

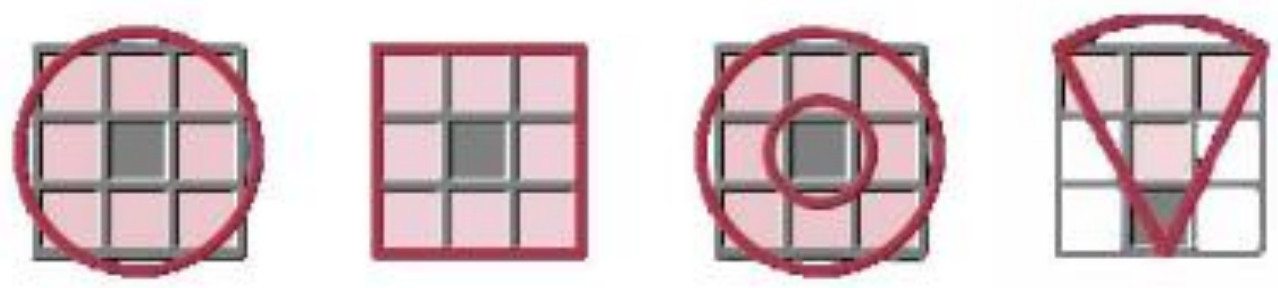

Fig. 1. Result example with neighbourhood analysis

\section{Result and Discussion}

\subsection{Profile of Jakarta Public Transport}

Development of public transport in Jakarta has been operated since a decades ago. This program planned as a solution to make better transportation in Jakarta who some solution have been tried before, like traditional transport modes with tram to overcome the transportation problems in Jakarta. Currently, there are evaluations of several types of public transport as well as some options of public transportation alternatives in order to cope with the traffic jam in Jakarta.

Trans Jakarta was a public transport system in Jakarta which adopted from mass transportation systems in the other cities who already applied before in the world, like Bogota, Tokyo etc. Trans Metro Jakarta has launched first in 2003 based from Transportation Ministry's policy and operated until now. It is a mass-transit in which passengers can only get on and off the bus at a designated stop. In this research, this type of public transport is called public transport with fixed stops.

Beside Trans Jakarta, Jakarta had also another type of public transport, like Metromini, angkot, and city bus. All of them also have designated stops, but peopke in Jakarta are rarely to use that for daily. Rather, people can get on or get off for the bus anywhere they want along its route. Therefore in this study, this types of public transport is called public transport with flexible stops.

This study used entire public transport line of both with fixed stops and flexible stops are evaluated for its performance, especially related to its spatial parameters, such as coverage area and blank spot area.

Trans Jakarta has 13 corridor with 1347 bus for all around Jakarta. Figure 2 showed about all route for Trans Jakarta. Every corridor divided by line colours.

\subsection{Public Transport Index for Public Transport}

Coverage area of public transport in Jakarta would measured for two type of modes, among others,

- First modes is public transport with flexible stops (metromini, angkot) by creating a buffer of 300 meter from the street that through that modes.

- Second modes is TransJakarta by creating a buffer of 300 meter, 500 meter, and 1 kilometer from the bus stops.

Coverage area of public transport decided by previous research, like public transport should be related with pedestrian (Kittelson \& Associates 1999; Layton 2017). Walking distance provided with people's ability to walk from and to the transit place. Walking distances should be decided before as plan or evaluation for the facility's performance. It is because there was a lack of consistency in the distances used among planners to make decisions related to walking (Layton 2017). Walking distance for people nearly considered by its speed. Many factors that affect walking speed, like walk with baby, walk with trolleys or carry anything even people walk in their facilities, like walkways, sidewalk etc. Other factors, like around the facility (including such things as pavement type, terrain, and impediments) affect pedestrian as well.In this research, walking distance has defined as a buffer that people could reach transit place. 
Buffering area that predicted by researcher found the number of ranging 0.125 miles as ideal distance,though $1 / 4$ mile and 0.5 miles was the most commonly used standard for determining walkable access (Layton 2017). This research used ranging 300,500, and 1000 meters for walkable access for public transport as the simplicity method that easy to measure and did not restricted by its range.

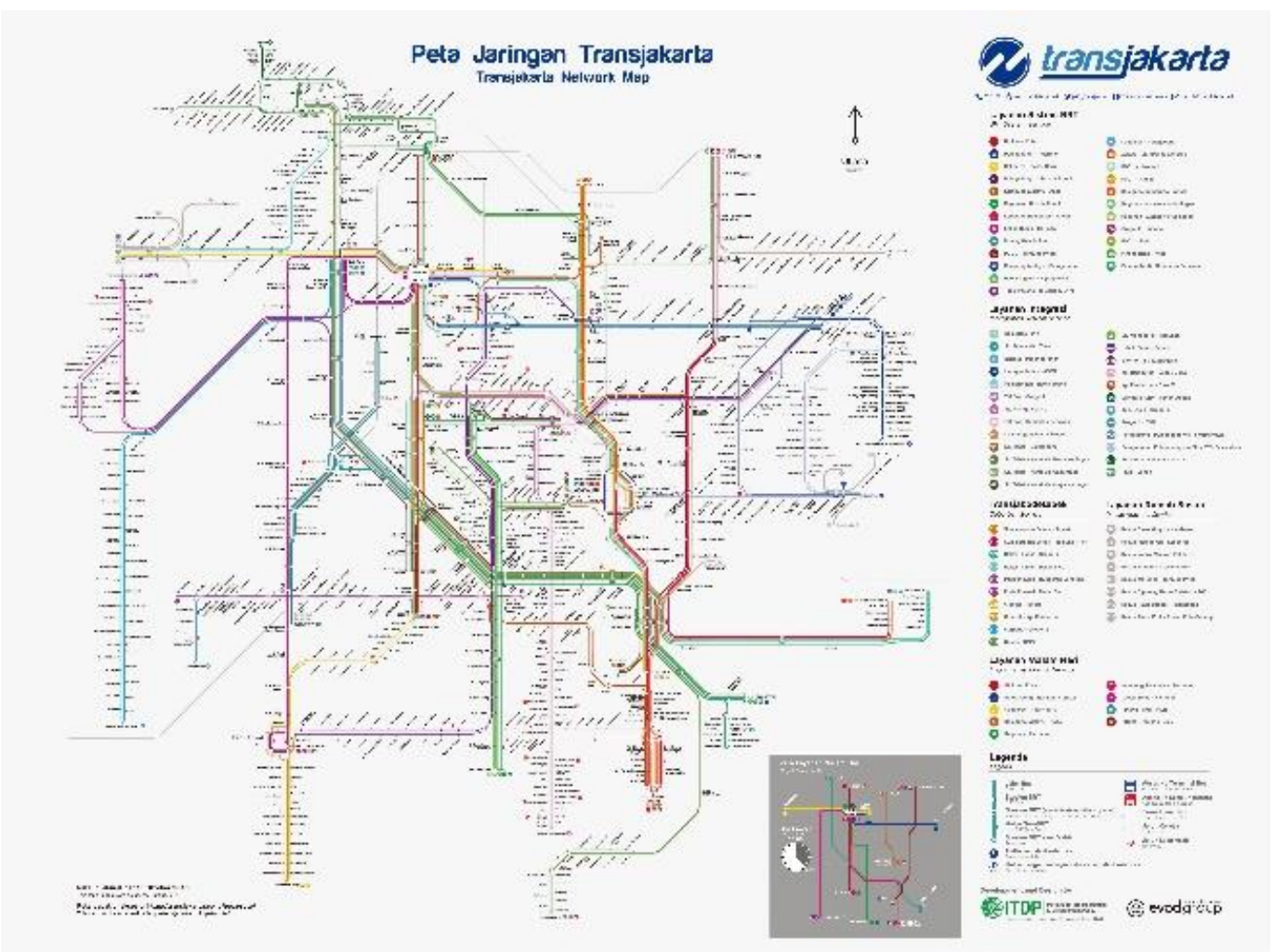

Fig 2. Trans Jakarta Route (Source : http://transjakarta.co.id/peta-rute/)

Beside, the area outside that coverage area was identified as blank spot or area without public transport service. The coverage area for first modes is about $69 \%$. In details, coverage area for each of the districts within Jakarta shown in Figure 3.

Coverage area of existing public transport is measured for TransJakarta by creating a buffer of 300 meter, 500 meter, and 1 kilometer from the bus stops. Beside, the area outside the coverage area is identified as blank spot or area without public transport service. For public transportation service with fixed stops (Trans Jakarta), the coverage area can be seen in the table 1 . 


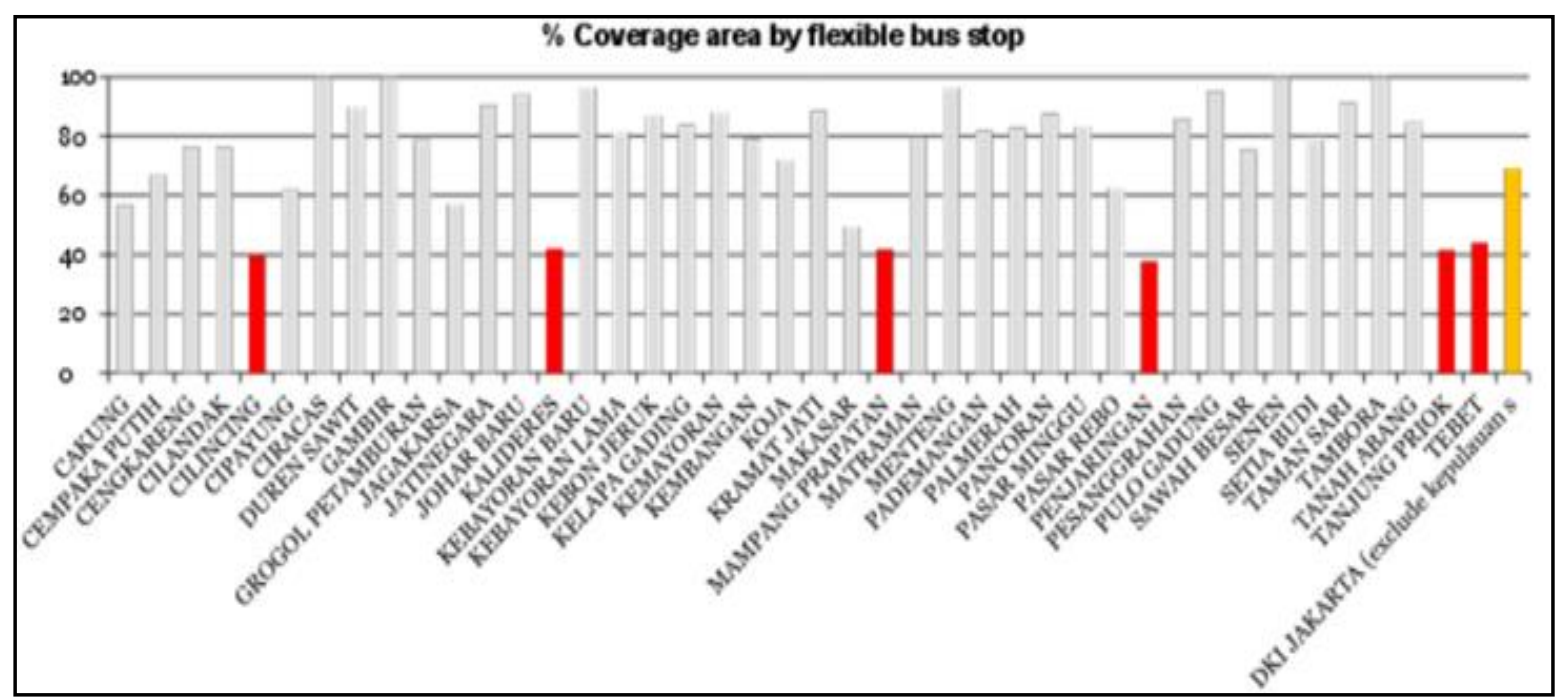

Fig 3. Coverage Area of Public Transportation by Districts

Table 1. Coverage Area of Trans Jakarta

\begin{tabular}{ccc}
\hline Assumed walking distance & Coverage area $\left(\mathrm{km}^{2}\right)$ & Percentage from total area \\
\hline $300 \mathrm{~m}$ & 51 & 7.78 \\
$500 \mathrm{~m}$ & 112 & 17.08 \\
$1000 \mathrm{~m}$ & 245 & 37.35 \\
\hline
\end{tabular}

\subsection{Public Transport Efficiency Based on the Potential Demand and Service Area}

In areas that are not covered by public transportation because the walking distance is farther than the accepted standard (300 meters), we evaluate the potential demand on those areas by two indicators. The first one is by population density, and the second one is by population within working age. Based from analysis, there are approximately 3.3 million population live in blank spot area.

Figure 5 showed about blank spot for Jakarta public transport which related to population density. There are regions detected as blank spot area with high density for the resident. That could be considered as potential market for alternative modes of transport, such as paratransit. For instance, Kemayoran and Matraman region which had red colours in the map. That colour means that region was a high density area in Jakarta, but all of public transport in Jakarta still not reach them all. This facts happened because of the narrow path of the residential areas. Therefore it is assumed that there are a lot of potential demand for on-demand microtransit modes in this area. 


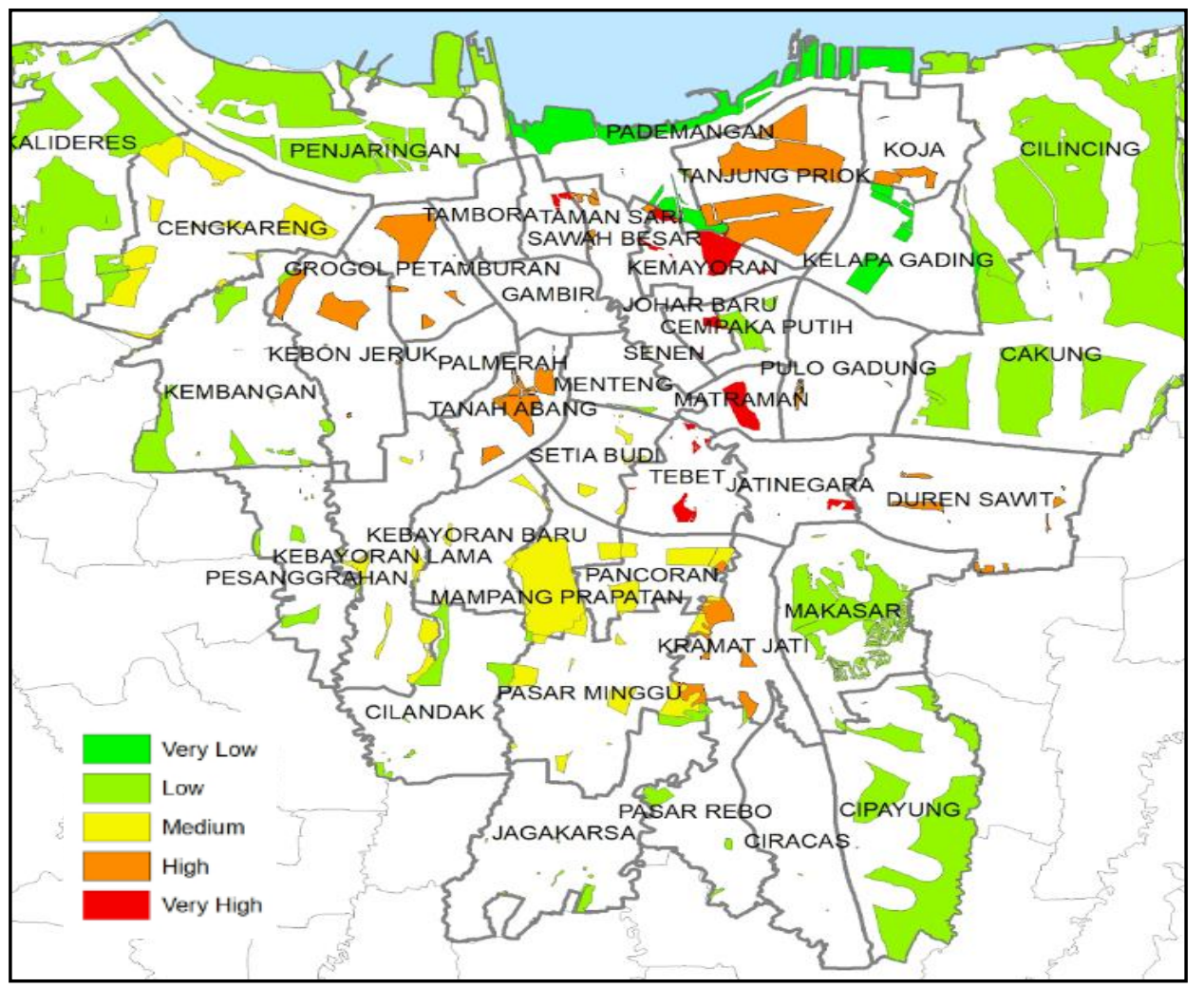

Fig 5. Population Density in Blank Spot Area

\section{Copyright}

Based on the analysis, it can be concluded:

1) There are many public transport blank spot areas in Jakarta. For instance, Transjakarta has only served about $7.78 \%$ for all Jakarta area which using 300 meters as an assumption for walking distance. If it used 500 meters for walking distance, it just reached about $17.08 \%$ for Jakarta area. Others, it just reached $37.35 \%$ for Jakarta area if it assumed walking distance about 1000 meters. Bedise, coverage area for flexible stop transport service was $69 \%$ with assumed for walking distance about 300 meters. So that, there is still ineffectiveness of public transport service in Jakarta.

2) In term of availability of public transport, there are still many areas with high density population and working age people that still not served by existing public transport service in Jakarta.

3) Approximately 3.3 million people in Jakarta live in blank spot areas.

\section{Acknowledgements}

The author would like to thank Pulse Lab Jakarta and the teams for their support in this research. 


\section{References}

BPS. (2017). Provinsi DKI Jakarta dalam angka 2015. https://jakarta.bps.go.id/publication/2016/02/29/bafeb8e753144624121e6123/provinsi-dki-jakarta-dalamangka-2015.html. Retrieved 20 May 2019.

Currie, G., Richardson, T., Smyth, P., Vella-Brodrick, D., Hine, J., Lucas, K., ... \& Stanley, J. (2010). Investigating links between transport disadvantage, social exclusion and well-being in Melbourne-Updated results. Research in transportation economics, 29(1), 287-295.

Dodson, J., Gleeson, B., \& Sipe, N. G. (2004). Transport disavantage and social status: a review of literature and methods. Australia: Urban Policy Program, Griffith University.

Ibanes, J.A.G. (2011). Transportation Planning in Rapidly Growing Cities: Lessons from Ho Chi Minh City, Jakarta and Mumbai, Melvin Webber Memorial Lecture. University of California at Berkeley.

Jaelani, L.M., \& Agung, B. C. 2018. Proximity Analysis. Surabaya: Teknik Geomatika-ITS.

Kausarian, H., Sri Sumantyo, J., putra, D., Suryadi, A., \& Gevisioner, G. (2018). Image processing of alos palsar satellite data, small unmanned aerial vehicle (UAV), and field measurement of land deformation. International Journal of Advances in Intelligent Informatics, 4(2), 132-141. doi:https://doi.org/10.26555/ijain.v4i2.221

Kittelson \& Associates. (1999). Transit Capacity and Quality of Service Manual. Washington DC: Kittellson \& Associates, Inc.

Layton, R. (2017). Tips For Locating Your Amenities. https://www.dcla.net/blog/walkability-standards. Retrieved 20 May 2019.

Lovelock, C., \& Gummesson, E. (2004). Whither services marketing? In search of a new paradigm and fresh perspectives. Journal of service research, 7(1), 20-41.

Lucas, K. (2012). Transport and social exclusion: Where are we now?. Transport policy, 20, 105-113.

Muttaqin, M. Z., \& Zaini, A. K. (2017). Pemilihan Sepeda Motor Sebagai Angkutan Reguler Mahasiswa Universitas Islam Riau (Studi Kasus: Fakultas Teknik). Jurnal Saintis, 17(2), 17-23.

Preston, J., \& Rajé, F. (2007). Accessibility, mobility and transport-related social exclusion. Journal of transport geography, 15(3), 151-160.

Ureta, S. (2008). To move or not to move? Social exclusion, accessibility and daily mobility among the low-income population in Santiago, Chile. Mobilities, 3(2), 269-289. 